\title{
Clonazépam, bromazépam et zolpidem dans les cheveux de victimes de soumission chimique : analyse quantitative par LC-MS/MS et relation dose-concentration
}

\section{Clonazepam, bromazepam and zolpidem in hair of victims of drug facilitated crimes: quantitative analysis by $L C-M S / M S$ and correlation with self-report}

Marjorie CHEZE, Marc DEVEAUX, Aurélie LENOAN, Gilbert PÉPIN*

Laboratoire TOXLAB, 7, rue Jacques Cartier - F-75018 Paris - France

*Corresponding Author: Gilbert PÉPIN, Laboratoire TOXLAB, 7, rue Jacques Cartier - F-75018 Paris - France Tel : +33 158592800 - Fax : +33158592801 - E-mail : toxlab@wanadoo.fr

(Reçu le 7 novembre 2005 ; accepté le 17 décembre 2005)

\section{RÉSUMÉ}

Depuis environ trois années nous avons analysé, sur Paris et trois zones de banlieue, des prélèvements biologiques de victimes de viol ou de vol pour lesquelles une soumission chimique était suspectée. Une précédente étude publiée montrait que sur 23 cas de soumission chimique avérée, de juin 2003 à mai 2004, les prévalences du zolpidem, du clonazépam et du bromazépam étaient les plus élevées, suivies par d'autres benzodiazépines, hypriotiques ou stupéfiants illicites. Nos récentes statistiques de juin 2004 à octobre 2005 sur 68 cas avérés, montraient la même prévalence. Le but de cette étude était donc d'établir, dans la mesure du possible, une relation dose-concentration dans les cheveux pour le zolpidem, le clonazépam (7-NH $\mathrm{N}_{2}$ clonazépam) et le bromazépam, afin d'interpréter les concentrations retrouvées dans les cas de soumission chimique. Des segments de $2 \mathrm{~cm}$. étaient utilisés pour les analyses ( $\sim 2$ mois). Une éventuelle

\section{SUMMARY}

Over a three-year period in the city of Paris and three suburbs, we tested biological specinens in victims of sexual. assaults or robbery in which involvement of psychoactive substances was suspected. A previous published study from June 2003 to May 2004 indicated that for 23 real drug-facilitated crimes (DFC) the prevalence of zolpidem, clonazepam and bromazepam were high, followed by other benzodiazepines and hypnotics or illicit drugs. Our new statistics from June 2004 to October 2005 on 68 real DFC cases, showed the same prevalence. The aim of this work was then to assess, as far as possible, the relationship between doses and concentrations of zolpidem, clonazepam (7-NH $\mathrm{N}_{2}$ clonazepam) and bromazepam in hair; according to self-reported intake, for the interpretation of concentrations found in cases of DFC. Hair samples were from victims, healthy volunteers and patients and were collected 4 to 8 weeks after the inta- 
différentiation selon la couleur ne pouvait être établie devant le faible nombre de cas. Les courbes de calibration (I-100 pg/mg) étaient préparées par ajout de quantités connues sur des aliquotes de matrice vierge. Les courbes étaient linéaires : $r^{2}=0,9847 ; 0,9996$ et 0,9997 pour le 7$\mathrm{NH}_{2}$ clonazepam, le bromazepam et le zolpidem, respectivement. Les LOD étaient de 0,5; 0,2 et 0,2 pg/mg. L'analyse segmentaire des cheveux de volontaires sains, de patients et de certaines victimes nous permettait d'établir une relation dose-concentration, fonction des déclarations de chacun. Nous avons ainsi pu mesurer des concentrations (en pg/mg) dans les phanères pour des doses uniques de $1 / 2$ à 2 comprimés de 2 à $12(n=6)$ en $7-N H_{Z}$ clonazépam, de 2,8 à 12 $(n=6)$ en bromazépam et de 1,2 à $19(n=15)$ en zolpidem; elle étaient pour plusieurs comprimés de 14 à $90(n=6), 22$ à $86(n=14)$ et 34,5 à $217(n=15)$ respectivenent; et pour un traitement quotidien faible à fort, de 31 à $418(n=14), 47$ à $6293(n=14)$ et 354 à $926(n=12)$ respectivement. Quelques cas d'empoisonnements montraient des concentrations de $371(n=1)$ en $7-\mathrm{NH}_{2}$ clonazépam et de 121 à $665(n=2)$ en bromazépam. Un cas de toxicomanie au zolpidem (10-30 cp/jour) montrait des concentrations selon les segments de 2534 à $9197 \mathrm{pg} / \mathrm{mg}$. Nos concentrations en bromazépam et 7-NH $\mathrm{H}_{2}$-clonazépam précédemment publiées n'étaient pas inclues, celles-ci ayant été déterminées sur des segments de $1 \mathrm{~cm}$ de cheveux broyés. Nos résultats sont en accord avec les quelques cas précédemment publiés.

\section{Introduction}

A guideline has been published in France for sampling and analytical determinations for DFC (1) but reports of drug-facilitated crimes (DFC) are still a challenge for the toxicologist.

Apart from ethanol and cannabis, detected drugs are mainly short half-life benzodiazepines and benzodiazepine-like hypnotics, with or without ethanol (2-5). A previous published study from June 2003 to May 2004 indicated that for 23 real drug-facilitated cases (DFC) the prevalence of zolpidem, clonazepam and bromazepam was high, followed by other benzodiazepines and hypnotics or illicit drugs (6). Their sedative and anterograde amnesia properties are widely used for this purpose.

Even if urine and blood analyses are necessary, segmental hair analysis must be done to show the victim's drug abstinence outside the period of the offence and to establish that the concentration found is in accordance with a single intake. Moreover, when the victim lodges a complaint several days after the offence, hair analysis may still be the only proof of exposure.

Detecting benzodiazepines and benzodiazepines-like hypnotics given once at a single dose needs analysis by liquid chromatography-tandem mass spectrometry triple stage quadrupole (LC-ESI-MS/MS-TSQ) (7), but the interpretation of the results must be cautious and should be documented, as far as possible, by some kind of "reference values". ke. Two centimeter hair segments were used for experiment ( 2 months). Not enough positive samples were available to make a differentiation according to hair color. Standard curves (1-100 pg/mg) were prepared by spiking aliquots of blank hair and had $r^{2}=0.9847,0.9996$ and 0.9997 for 7 $\mathrm{NH}_{2}$-clonazepam, bromazepan and zolpidem, respectively. $L O D$ were $0.5,0.2$ and $2 \mathrm{pg} / \mathrm{mg}$ respectively. Hair analyses of victims, healthy volunteers and patients allowed us to establish the following dose-concentration correlations. Concentrations measured ( $\mathrm{pg} / \mathrm{mg}$ ) were: for single intake of

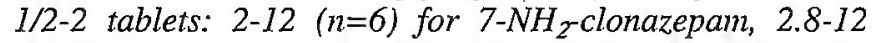
$(n=6)$ for bromazepam and 1.2-19 $(n=15)$ for zolpidem; for several tablets: $14-90(n=6), 22-86(n=14)$ and 34.5-217 $(n=15)$ respectively; for daily treatment (light to heavy): $31-$ $418(n=14), 47-6293(n=14)$ and 354-926 $(n=12)$. Some cases of non lethal poisoning showed the following concentrations ( $\mathrm{pg} / \mathrm{mg}$ ): $371(\mathrm{n}=1)$ for $7-\mathrm{NH}_{2}$-clonazepam and 121$665(n=2)$ for bromazepam. One case of addiction to zolpidem (10-30 tab/day) showed concentrations ranging from 2534 to $9197 \mathrm{pg} / \mathrm{mg}$ depending on the hair segment. We haven't included our previously published data for bromazepam and 7-NH - clonazepam since the segment length was different $(1-\mathrm{cm})$ and hair was powdered before extraction. Our new results are consistent with the few cases previously published.

The detection of benzodiazepines in segmented hair has been documented previously (7-11) even after a single dose $(5,7,12-15)$ but these few data in hair concentrations must be enlarged. The aim of this work was to assess the relationship between doses and concentrations of $7-\mathrm{NH}_{2}$-clonazepam, bromazepam and zolpidem in hair, according to self-reported intake, for the interpretation of concentrations found in drug facilitated cases using our methodology.

\section{Experimental Population}

Hair samples were taken from healthy volunteers, patients and victims. We analyzed hair extracts of healthy volunteers for the determination of zolpidem, clonazepam and bromazepam after a single oral dose of Stilnox ${ }^{\circledR} 10 \mathrm{mg}$ tablet, Rivotril® $2 \mathrm{mg}$ tablet and Lexomil® $6 \mathrm{mg}$ tablet (Controlled study by the French Society of Analytical Toxicology (Société Française de Toxicologie Analytique) after single therapeutic dose intake). We collected hair of a few patients with known therapeutic treatment (samples from hospital and other patients). Perfectly documented cases of DFC were also included in this study.

\section{Sample collection}

Strands of hair were collected one to two months after 
ingestion or after the alleged DFC, in order to minimize hair growth variability effect, and were stored at ambient temperature until analysis. Four hair strands (about 100 hairs each) were collected, cut directly above the skin in the vertex posterior position. At this time the suspected drug should be found only in the last one or two centimeters of the root side. They were of different colors, and some samples were bleached, dyed or tinged.

\section{Standards and reagents}

Zolpidem, bromazepam, clonazepam-d4, 7- $\mathrm{NH}_{2}$-clonazepam and 7- $\mathrm{NH}_{2}$-clonazepam-d4 were obtained from Cerilliant (LGC Promochem, France). Ammonium formate (min. 98\%), formic acid (99\%), methanol and $0.1 \mathrm{~N}$ sodium hydroxide (for analysis) and acetonitrile (HPLC grade RS Plus) were obtained from Carlo Erba, France. Dichloromethane and diethyl ether (Chromanorm HPLC grade) were obtained from Prolabo, France. PTFE filters $(0.2 \mu \mathrm{m} \times 25 \mathrm{~mm})$ were obtained from Alltech, France. Sorensen buffer was adjusted at $\mathrm{pH}$ 7.6, as previously described (7).

\section{Hair extraction}

Because of oral route administration of drugs tested and thus minimal probability of passive contamination, hair was washed twice for 5 minutes with dichloromethane for cleaning only fat residues. Clonazepam- $\mathrm{d} 4$ or 7- $\mathrm{NH}_{2}$-clonazepam-d4 (internal standards, $100 \mathrm{pg} / \mathrm{mg}$ each) were added to $20 \mathrm{mg}$ of decontaminated hair, finely cut with scissors. Matrix extraction was performed by incubation one night at $56^{\circ} \mathrm{C}$ in Sorensen buffer pH 7:6 for bromazepam and zolpidem, and by incubation $15 \mathrm{~min}$ at $95^{\circ} \mathrm{C}$ in $\mathrm{NaOH} 0.1 \mathrm{~N}$ for $7-\mathrm{NH}_{2}$-clonazepam. Liquid-liquid extraction was then carried out with $2 \mathrm{~mL}$ dichloromethane/diethyl ether (80/20). After centrifugation, the organic layer was filtered with PTFE $0.2 \mu \mathrm{m}$ then evaporated to dryness. The residues were reconstituted by $60 \mu \mathrm{L}$ of methanol/acetonitrile $(50 / 50)$ and transferred in glass vials. Ten microliters were injected into the chromatographic system.

\section{Apparatus}

As previously described (7) the liquid chromatographic separation was carried out using an HPLC (Surveyor, ThermoElectron) fitted with an Uptisphere ODB C18 column (150 × $2 \mathrm{~mm}, 5 \mu \mathrm{m})$ (Interchim, France). Mobile phase initial conditions were $85 \%$ formate buffer $2 \mathrm{mM}$ pH 3 and $15 \%$ acetonitrile (v/v) delivered at a flow of $200 \mu \mathrm{L} / \mathrm{min}$ and held $0.5 \mathrm{~min}$, then increased to $10 / 90$ up to $10 \mathrm{~min}$ and re-equilibrated for $7 \mathrm{~min}$ at initial conditions.

The detection was performed on a triple stage quadrupole (TSQ Quantum, ThermoElectron), fitted with an electrospray ionization (ESI) Ion Max source, and allo- wed the simultaneous detection of benzodiazepines in positive polarity and Multiple Reaction Monitoring (MRM) mode. To each pseudo-molecular ion $[\mathrm{MH}]^{+}, 3$ product ions were acquired (table I) at a scan time of $0.1 \mathrm{~s}$ with a width of 1 a.m.u. For the optimization of detection conditions, direct infusions of standard solutions $(10 \mu \mathrm{L} / \mathrm{mL})$ were done with mobile phase. For screening, spray voltage was optimized at $4600 \mathrm{~V}$ and capillary temperature was set at $360^{\circ} \mathrm{C}$. Tube lens was near $100 \mathrm{~V}$. Ion sweep gas, sheath gas and auxiliary gas flow were optimized respectively at 5, 30 and 5 (arbitrary units). Collision cell pressure was set at $1.5 \mathrm{mTorr}$ of argon and collision energies were optimized for a maximum detection of each product ion.

Table I : SRM transitions for the detection of 7-NH2-clonazepam, bromazepam and zolpidem by LC-ESI-MS/MS.

\begin{tabular}{|c|c|c|c|c|c|}
\hline & [MH] ${ }^{+}$ & $\mathbf{D}_{1}$ & $\mathrm{D}_{2}$ & $\mathbf{D}_{3}$ & $\begin{array}{c}\text { RT } \\
( \pm 0: 05 \mathrm{~min})\end{array}$ \\
\hline 7- $\mathrm{NH}_{2}$-clonazepam-d4 (IS) & 290.3 & 254 & 226 & 199 & 7.6 \\
\hline 7- $\mathrm{NH}_{2}$-clonazepam & 286.0 & 250 & 222 & 195 & 7.7 \\
\hline clonazepam-d4 (IS) & 319.9 & 274. & 245 & 218 & 10.8 \\
\hline bromazepam & 316.03 & 288 & 261 & 209 & 9.6 \\
\hline zolpidem & 308.3 & 263 & 235 & 219 & 8.0 \\
\hline
\end{tabular}

\section{Results and discussion}

\section{Validation data}

Calibration curves were prepared by spiking aliquots of blank hair at concentrations for 7- $\mathrm{NH}_{2}$-clonazepam, bromazepam and zolpidem, ranging from $1-100 \mathrm{pg} / \mathrm{mg}$ and from $100-1000 \mathrm{pg} / \mathrm{mg}$. Curves were linear in those ranges with equal weighting and had $\mathrm{r}^{2}$ for $1-100 \mathrm{pg} / \mathrm{mg}$ calibration curves of $0.9847,0.9996$ and 0.9997 for $7-\mathrm{NH}_{2}$-clonazepam, bromazepam and zolpidem, respectively.

The limits of detection (LOD) were evaluated with decreasing concentrations of the drugs spiked in drugfree hair, until a response equivalent to three times the background noise was observed. The limits of quantification (LOQ) were considered the concentration of analyte at which the dosage has an accuracy $<20 \%$ and a maximum of $20 \%$ variations on relative abundances for MRM spectra (Table II).

Table II : Limits of detection (LOD) and quantification (LOQ) for $7-\mathrm{NH}_{2}$-clonazepam, bromazepam and zolpidem in hair by LC-ESI (Ion Max)-MS/MS.

\begin{tabular}{|lcc|}
\hline & $\begin{array}{c}\text { LOD } \\
(\mathrm{pg} / \mathrm{mg})\end{array}$ & $\begin{array}{c}\text { LOQ } \\
(\mathrm{pg} / \mathrm{mg})\end{array}$ \\
\hline 7- $\mathrm{NH}_{2}$-clonazepam & 0.5 & $\mathrm{I}$ \\
bromazepam & 0,2 & 2 \\
zolpidem & 0.2 & 1 \\
\hline
\end{tabular}




\section{Results for zolpidem}

Zolpidem (Stilnox®) is a hypnotic agent, imidazopyridine derivative, with a chemical structure different from benzodiazepines. A single oral administration of 5 to 10 mg of zolpidem leads to an average plasma concentration of $59 \mathrm{ng} / \mathrm{mL}$ ( 29 to $113 \mathrm{ng} / \mathrm{mL}$ ) and $121 \mathrm{ng} / \mathrm{mL}(58$ to $272 \mathrm{ng} / \mathrm{mL}$ ) respectively, at 1.6 hours after ingestion, with a half-life of 2.6 hours (16). During chronic therapy, average plasma concentrations may not vary. Therefore, hair concentration ranges presented in Table III were quite proportional between single doses and daily treatment. The concentrations we found in hair were consistent with the few cases previously published by Villain et al. (17) for single dose of zolpidem: 1.8-9.8 $\mathrm{pg} / \mathrm{mg}(\mathrm{n}=3)$. One case of self-reported addiction with zolpidem was illustrated by very high concentrations found in segmental hair analysis.

Table III : Dose-concentration correlations for zolpidem in hair, according to self-reported intake over two month's period.

\begin{tabular}{|c|c|c|c|}
\hline \multirow{2}{*}{ Tablet dosage : $10 \mathrm{mg}$} & \multirow[t]{2}{*}{ Total dose (2 months) } & \multicolumn{2}{|c|}{ Concentrations (pg/mg) } \\
\hline & & & \\
\hline Single dose & $\sim 5-20 \mathrm{mg}$ & $1.2-19$ & $(\mathrm{n}=15)$ \\
\hline Several tablets & $-30-300 \mathrm{mg}$ & $34.5-217$ & $(n=15)$ \\
\hline Daily treatment & $\sim 300-900 \mathrm{mg}$ & $354-926$ & $(\mathrm{n}=12)$ \\
\hline Addiction (10-30 tab/day) & y) $\sim 3000-9000 \mathrm{mg}$ & $2534-9197$ & $(\mathrm{n}=1)$ \\
\hline
\end{tabular}

\section{Results for clonazepam}

Clonazepam (Rivotril@) is an anti-convulsive prescribed mostly as antiepileptic agent. Sometimes it is prescribed as sedative or anxiolytic and drops are often used in that case. Bottles of 500 drops $(20 \mathrm{~mL})$ are selling for a dosage of $0.1 \mathrm{mg} / \mathrm{drop}$. The main adverse effect of clonazepam is drowsiness, which occurs in about $50 \%$ of all patients on starting therapy (18). A single oral administration of $2 \mathrm{mg}$ of clonazepam leads to an average plasma concentration of $17 \mathrm{ng} / \mathrm{mL}$ ( 7 to $24 \mathrm{ng} / \mathrm{mL}$ ) between 1 and 4 hours after ingestion, with a half-life of 19 to 42 hours ( 8 subjects). During chronic therapy with $6 \mathrm{mg} /$ day, plasma concentrations reach 29 to $75 \mathrm{ng} / \mathrm{mL}$ for clonazepam, and 23 to $137 \mathrm{ng} / \mathrm{mL}$ for 7- $\mathrm{NH}_{2}$-clonazepam (16). The higher concentration and the chemical properties of amino-metabolite explain that 7- $\mathrm{NH}_{2}$-clonazepam is the major compound found in hair after oral intake. But according to our own experience, different routes of administration may lead to different ratios of active molecule to metabolite in hair.

There is also a great variability in oral dosage for therapeutic indications (from some drops of clonazepam to induce sleeping to epileptic treatment or heavy psychiatric treatment) that can leads to large ranges of concentrations for so called "daily treatment". Nevertheless, our results presented in Table IV were consistent with the few cases previously published by Negrusz et al. (13) for 7- $\mathrm{NH}_{2}$-clonazepam at single dose: $1.8-23 \mathrm{pg} / \mathrm{mg}(\mathrm{n}=6)$ or after psychiatric treatment: $1.37-1267 \mathrm{pg} / \mathrm{mg}(\mathrm{n}=9)$.

We haven't included our previously published data for 7$\mathrm{NH}_{2}$-clonazepam (7) since the segment length was different $(1-\mathrm{cm})$ and hair was powdered before extraction.

Table IV : Dose-concentration correlations for 7- $\mathrm{NH}_{2}$-clonazepan in hair; according to self-reported intake of clonazepam over two month's period.

\begin{tabular}{|c|c|c|c|}
\hline \multirow[b]{2}{*}{ Tablet dosage : $2 \mathrm{mg}$} & \multirow[t]{2}{*}{ Total dose ( 2 months) } & \multicolumn{2}{|c|}{ Concentrations (pg/mg) } \\
\hline & & & \\
\hline Single dose & $\sim 2-28 \mathrm{mg}$ & $2-12$ & $(\mathrm{n}=6)$ \\
\hline Several tablets or drops & $\sim 10-50 \mathrm{mg}$ & $14-90$ & $(n=6)$ \\
\hline Daily treatment & $\sim 75-300 \mathrm{mg}$ & $31-418$ & $(n=14)$ \\
\hline $\begin{array}{l}\text { Non lethal poisoning by one } \\
\text { single dose }\end{array}$ & $\sim 50 \mathrm{mg}$ & 371 & $(n=1)$ \\
\hline
\end{tabular}

\section{Results for bromazepam}

Bromazepam (Lexomil@) is widely prescribed in European countries as an anxiolytic but also exhibits sedative and hypnotic properties. Following a single administration of $12 \mathrm{mg}$ to 10 subjects, an average peak plasma concentration of bromazepam of $131 \mathrm{ng} / \mathrm{mL}$ (107 to $173 \mathrm{ng} / \mathrm{mL}$ ) was achieved between 1 and 4 hours, declining with an average half-life of 11.9 hours (7.9 to 19.3 hours) (16).

Even if the range of concentrations in blood for a given dose is quite narrow, a great variability in oral dosage for therapeutic indications can lead to large ranges of concentrations for daily treatment. Nevertheless, our results presented in Table $\mathrm{V}$ were consistent with the few cases previously published by Villain et al. (15) for single dose of bromazepam: $0.8-4.7 \mathrm{pg} / \mathrm{mg}(\mathrm{n}=2)$.

We haven't included our previously published data for 7 $\mathrm{NH}_{2}$-clonazepam (7) since the segment length was different $(1-\mathrm{cm})$ and hair was powdered before extraction.

Table V : Dose-concentration correlations for bromazepam in hair; according to self-reported intake over two month's period.

\begin{tabular}{|lccl|}
\hline & Total dose (2 months) & Concentrations (pg/mg) \\
\hline Tablet dosage : $6 \mathrm{mg}$ & & & \\
Single dose & $\sim 6-12 \mathrm{mg}$ & $2.8-12$ & $(\mathrm{n}=6)$ \\
Several tablets & $\sim 18-90 \mathrm{mg}$ & $22-86$ & $(\mathrm{n}=14)$ \\
$\begin{array}{l}\text { Daily treatment } \\
\begin{array}{l}\text { Non lethal poisoning by one } \\
\text { single dose }\end{array}\end{array}$ & $\sim 90-2160 \mathrm{mg}$ & $47-6293$ & $(\mathrm{n}=14)$ \\
\hline
\end{tabular}




\section{Conclusion}

If possible, segmental hair analysis must be carried out in all case of DFC to show the victim's drug abstinence outside the period of the offence and to establish that the concentration found is in accordance with those found for a single intake. Moreover, when the victim lodges a complaint several days after the offence, hair analysis may still be the only proof of exposure.

Recent statistics gathered in our laboratory for DFC from June 2004 to October 2005 showed that in 68 real cases, the prevalence is the highest for zolpidem (24.4\%), clonazepam (17.7\%) and bromazepam (17.7\%). Zopiclone was found in $11.1 \%$ of DFC, followed by lorazepam, midazolam, diazepam and others. We can also confirm that flunitrazepam is no longer in connection with DFC in France. These results are similar to those we previously published in the same area (6).

With some of these documented cases as well as healthy volunteers (controlled study by the French Society of Analytical Toxicology (Société Française de Toxicologie Analytique) after single therapeutic intake) and patients (samples from hospital and other patients), we were able to establish a relationship between dose and concentrations in hair for the three most common drugs (zolpidem, 7- $\mathrm{NH}_{2}$-clonazepam and bromazepam) found in DFC and to differentiate one single dose from occasional consumption or daily treatment. What makes matters more complex is the fact that one must keep in mind that a single intake could be of numerous tablets or drops and, further more, many factors such as natural variability of hair growth (person, season, age...), hair color and cosmetic treatments can lead to a great variability of concentrations in scalp hair. Sample collection should be done carefully to avoid any shift, and always in the same area because of variability of hair growth depending on anatomic sites, and not too late after the suspected intake to avoid any false negative. Therefore the interpretation of concentrations in hair must be cautious.

Pubic and axillary's hair analysis must be avoided to document cases of DFC since their growth cycles are different from scalp hair. Nevertheless, they could be analyzed in this field but without segmentation and only if analyses of blood and urine show drug presence and if inquiry is consistent with DFC.

\section{Acknowledgements}

The authors express their sincere thanks to the French Society of Analytical Toxicology (Société Française de Toxicologie Analytique) for their healthy volunteers and F. Brion (Unité Médico Légale, Versailles), F. Questel (Unité Médico Judiciaire, Hôtel-Dieu, Paris), A. Soussy (Unité de Consultation Médico Judiciaire, Créteil) and P. Werson (Unité de Consultation Médico Judiciaire, Evry) for providing biological samples and case histories.

\section{References}

1. Société Française de Toxicologie Analytique, Consensus. Soumission chimique : prise en charge toxicologique. Ann. Toxicol. Anal. 15: 239-242 (2003).

2. M. LeBeau, W. Andollo, W. Lee Hearn, R. Baselt, E. Cone, B. Finkle, D. Fraser, A. Jenkins, J. Mayer, A. Negrusz, A. Poklis, H.C. Walls, L. Raymon, M. Robertson and J. Saady. Recommendations for toxicological investigations of drugfacilitated sexual assaults. J. Forensic Sci. 44: 227-230 (1999).

3. P. Kintz, V. Cirimele, M. Villain, A. Tracqui and B. Ludes. Soumission chimique: approches pratiques en toxicologie médico-légale. Ann. Toxicol. Anal. 14: 361-364 (2002).

4. M.A. ElSohly and S.J. Salamone. Prevalence of drugs used in cases of alleged sexual assault. J. Anal. Toxicol. 23: 141146 (1999).

5. G. Pépin, M. Chèze, G. Duffort and F. Vayssette. Interest of hair and tandem mass spectrometry for chemical submission: about several cases. Ann. Toxicol. Anal. 14: 395-406 (2002).

6. M. Chèze, G. Duffort, M. Deveaux and G. Pépin. Hair analysis by liquid chromatography-tandem mass spectrometry in toxicological investigation of drug facilitated crimes: Report of 128 cases over the period June 2003-May 2004 in metropolitan Paris. Forensic Sci. Int. 153: 3-10 (2005).

7. M. Chèze, M. Villain and G. Pépin. Determination of bromazepam, clonazepam and metabolites after a single intake in urine and hair by LC-MS/MS. Application to forensic cases of drug facilitated crimes. Forensic Sci. Int. 145: 123130 (2004).

8. M.A. ElSolhy. Drug facilitated sexual assault. South. Med. J. 94: 655-656 (2001).

9. R. Kronstrand, I. Nystrom, M. Josefsson and S. Hodgins. Segmental ion spray LC-MS-MS analysis of benzodiazepines in hair of psychiatric patients. J. Anal. Toxicol. 26: 479-484 (2002).

10. M. Yegles, F. Mersh and R. Wenning. Detection of benzodiazepines and other psychotropic drugs in human hair by GC/MS. Forensic Sci. Int. 84: 211-218 (1997).

11. A. El Mahjoub and C. Staub. Determination of benzodiazepines in human hair by on-line high-performance liquid chromatography using a restricted access extraction column. Forensic Sci. Int. 123: 17-25 (2001).

12. A. Negrusz, C.M. Moore, J.L. Kern, P.G. Janicak, M.J. Strong, N.A. Levy. Quantitation of clonazepam and its major metabolite 7-aminoclonazepam in hair. J. Anal. Toxicol. 24: 614-620 (2000).

13. A. Negrusz, C.M. Moore, K.B. Hinkel, T.L. Stockham, M. Verma, M.J. Strong and P.G. Janicak. Deposition of 7-aminoflunitrazepam and flunitrazepam in hair after a single dose of Rohypnol. J. Forensic Sci. 46: 1143-1151 (2001).

14. A. Negrusz, A.M. Bowen, C.M. Moore, S.M. Dowd, M.J. Strong and P.G. Janiak. Deposition of 7-aminoclonazepam and clonazepam in hair following a single dose of Klonopin. J. Anal. Toxicol. 26: 471-8 (2002).

15. M. Villain, M. Chèze, V. Dumestre, B. Ludes and P. Kintz. Hair to document drug-facilitated crimes : four cases involving bromazepam. J. Anal. Toxicol. 28: 516-19 (2004).

16. R.C. Baselt. Disposition of toxic drugs and Chemicals in Man, Chemical Toxicology Institute, Foster city, California, 2000, pp 896, 94, 194.

17. M. Villain, M. Chèze, A. Tracqui, B. Ludes and P. Kintz. Windows of detection of zolpidem in urine and hair: application to two drug facilitated sexual assaults. Forensic Sci. Int. 143: 157-61 (2004).

18. K. Parfitt, Martindale, The complete drug reference, Parmaceutical Press, 1999, pp 343. 